\title{
Problems in the Design of a Marine Transportation System for the Arctic
}

\author{
L. F. LIDDLE and W. N. BURRELL1
}

\begin{abstract}
During the past decade, the need to transport oil and other cargoes through the waters of the Arctic has resulted in an increase in knowledge and understanding of the operational problems involved. The techniques of transportation systems analysis as developed for open-water shipping, together with a careful economic analysis of the special problems of operation in icebound waters, may provide the key to the development of an economically-viable marine transportation system for the Arctic.
\end{abstract}

RÉSUMÉ. Problèmes dans l'étude d'un système de transport maritime pour l'Arctique. Au cours de la dernière décennie, le besoin de transporter du pétrole ou d'autres cargaisons dans les eaux de l'Arctique a conduit à une meilleure connaissance et à une meilleure compréhension des problèmes techniques que cela implique. Les techniques d'analyse des systèmes de transport mises au point pour la navigation en eau libre et une analyse économique soignée des problèmes particuliers aux opérations dans les eaux englacées pourraient fournir la clé du développement d'un système de transport maritime économiquement viable pour l'Arctique.

РЕЗЮМЕ. Проблемы, возникаюиие при разработке морских транспортных систем $\partial л я$ Арктики. В течение последнего десятилетия потребность в транспортировке нефти и других грувов в арктических водах привела к увеличению знаний и понимания связанных с этими операциями проблем. Метод анализа транспортных скстем, разработанный для судоходства в открытых водах, в сочетании с тщательным экономическим аналивом специфики судоходства в скованных льдом водах может помочь установлению экономически вытодной системы морского транспорта для Арктики.

\section{BACKGROUND}

Arctic resources and the quest for the Northwest Passage to the Orient have provided the principal impetus towards the use of seagoing vessels in the Arctic. Scarcely five years after Columbus's first voyages, John Cabot attempted to reach Cathay via a northern route. During the 16th and early 17 th century, Europeans sought to find the key to the northerly shipping route which they believed would provide them with easy access to profitable oriental trade.

Within the last decade, the tremendous mineral deposits existing in the Arctic have attracted the interest of industry and government. This interest has been expressed in the commitment of manpower and money to projects there on a scale previously inconceivable. As a consequence, public interest has been aroused to a degree only exceeded among technical and scientific projects by the space programme.

1Sun Shipbuilding and Dry Dock Company, Chester, Pennsylvania, U.S.A. 
The experiments in the Arctic with the oiltanker S.S. Manhattan by the Humble Oil and Refining Company in 1969 and 1970 were the most publicly visible attempts to master the unusual conditions of navigation in the northern seas. The 150,000-ton Manhattan was converted to icebreaking service in order to verify the existing knowledge of Arctic shipping technology and the ability of ships to navigate from place to place in ice. She performed well in ice; she broke it and navigated in it and the results indicated that an icebreaker transportation system operating through the Northwest Passage might possibly be an economic method of moving the newly-discovered Alaskan North Slope oil to the very large East Coast market. However, the ultimate decision by Humble was to cast its lot in with the Trans-Alaska Pipeline.

The exploitation of the oil found on the North Slope of Alaska makes necessary, however, the regular movement of oceangoing vessels in the Arctic, at least until the Pipeline is in service. Although the flotilla of barges which plies during the ice-free season between the Seattle-Vancouver area, Prudhoe Bay, Alaska and the Mackenzie delta area does not challenge the strength of the Arctic ice, it constitutes a working water transportation system, the satisfactory operation of which depends upon man's knowledge of Arctic sea ice. Nearly 70,000 tons of supplies were moved from the west coast to the oilfields during the summer of 1974. While the effort involved in this movement is substantial due to the unusual nature of the cargoes carried and their lack of homogeneity, it is interesting to note that when the Trans-Alaska Pipeline opens, the daily weight of oil delivered will nearly equal the largest shipments by barge in 1970, which amounted to 180,000 tons.

The petroleum potential of the island area of the Canadian Arctic has also inspired a successful assault on the interisland ice which has, however, received substantially less publicity than did the Manhattan experiment. During the summers of 1973 and 1974, the Canadian sealing vessel M.V. Carino sailed the interisland waters trailing a seismic streamer for Geophysical Services, Inc., of Calgary, Alberta. In order to reach open waters where it could most effectively perform its seismic mission, the Carino had to battle its way through the ice floes which remain during the summer breakup. During the 1973 season, the Carino, manned by Canadians and Norwegians, broke through old ice as thick as eighteen feet. During 1974, the crews of the Carino and of a similar vessel, the M.V. Arctic Explorer, took advantage of unusually open waters in M'Clure Strait and succeeded in shooting over 1,300 miles of seismic lines in M'Clure and Fitzwilliam Straits. The Arctic Explorer became the first ship to be seen by the personnel at the weather station at Mould Bay, and both it and the Carino stole from the Canadian Coast Guard icebreaker John A. Macdonald the distinction of having gone furthest west in M'Clure Strait.

The three assaults on the Arctic just mentioned were born of an economic need. In each case the vessels made some progress against ice and other difficult environmental conditions. The successes achieved keep alive the hope that an economically viable transportation system for the Arctic will eventually be found and put into operation. The problems involved form the subject of the present paper. 


\section{THE DESIGN OF ICEBREAKERS}

Until recently, icebreaking vessels were little used for commercial operations, and then only in areas where the ice was relatively thin in comparison with that of the Arctic.

It is fairly generally known that only a small part of the propulsion energy of icebreakers is expended in breaking the ice; most of it is spent in moving the ice to the side of the vessel. This circumstance provides direct support for the argument that propulsion energy and the beam of the vessel are more highly interrelated when ice is present than in the open-water condition (German et al. 1971).

At this point it might simply be stated that the power plant should be of a size sufficient to overcome maximum resistance. It is necessary, however, to decide what minimum speed is acceptable. In order to optimize among alternatives, it will be necessary to have a method to predict speed/power relationship in nonuniform ice fields which is adaptable to computers.

Speed/power prediction methods involving regression techniques have been used in the past for particular hull forms and bow shapes (Levine et al. 1974). The indications are, however, that the appropriate choice of the latter will be influenced by the thickness, hardness and pressures of the ice in a given operating area. It would be advantageous therefore to have available a defined procedure for evaluating the effect on speed/power relationship of bow shapes and hull forms. The best optimizing method would accordingly be one which took account of the real situation of operating partly in brash ice, partly in open leads, partly breaking ridges, and partly in uniform fields (Milano 1973).

Vessels operating in ice require more power than conventional vessels operating in open water, regardless of the outcome of any speed/power analysis. Most modern icebreakers may be regarded as protective steel envelopes for a crew and a power plant. Since no space is required in them for cargo and the economics of fuel consumption is not a major problem, the design of propulsion machinery for icebreakers has not generally been the same as in the case of commercial ships. Nuclear power has been used by the Russians; U.S. Coast Guard icebreakers of the new Polar Star class are equipped with high-speed diesel engines and aircraft-derived gas turbines; and older icebreakers have diesel-electric propulsion. None of these systems of propulsion, however, is common in normal commercial vessels.

The development of an economic power plant which can respond to the changing power loads experienced in Arctic operations is an extremely important requirement. With the cost of oil rising as it is at present, economy in the use of fuel has become one of the major operating concerns of shipowners. It would, therefore, be highly desirable to maintain a fuel consumption of less than $0.5 \mathrm{lb}$. per shaft horse power per hour of bunker " $C$ " fuel oil for the entire range of operating power. Electric drive with multiple prime movers would provide one means of maintaining an economic level of fuel consumption over a wide range of power output, and provide the vessel with full reversing facilities. A second alternative would be to have controllable-pitch propellers. The alternatives need 
not be mutually exclusive; however, in holding down the total cost of operation it is desirable to keep the power plant simple and easily maintainable (Bustard 1973).

Where there are varying power loads, it is difficult to maintain normal economies because most marine power plants are designed to operate within a very narrow range of power output. Maintaining fuel efficiency despite the increase in appendage resistance of multi-screwed vessels, the wide variation of power loads and the more confining constraints on space and cost is an extremely important matter that requires special treatment.

The commodities which are being considered for transport from the Arctic by sea are bulk ores, oil and liquid natural gas. Historically, transport systems for such commodities have been cost-of-service oriented, with an emphasis on economies of scale in vessel design. Introducing a bulk-type vessel into the Arctic environment presents certain special problems in designing the cargo containment area and the ballast capacity of the vessel.

When a vessel is operating in ice, a major requirement is for its bow to be of optimum design for icebreaking. Two courses of action appear to be available to achieve this. One is to have a two-step bow which, however, would only work with relatively thin ice (Levine et al. 1974). The other, necessary with heavy icebreaking operations, is to ballast the vessel to an operational draught similar to that for full load. Design of a ship for $100 \%$ ballast capacity is quite feasible for an ore carrier, where the cargo has a low stowage factor. Tankers, however, under the new rules of the International Maritime Consultative Organization, will have to carry only about $38-52 \%$ of their cargo deadweight in clean ballast. If conditions in the Arctic require that vessels be built of $100 \%$ cargo deadweight in clean ballast, additional economic losses will result from the use of these vessels. To eliminate this problem, consideration should be given to the provision of ballast-water separating facilities at the Arctic loading area, or mandatory tank cleaning at port of discharge, prior to ballasting.

Protection of the cargo and prevention of damage to the environment must be a prime concern in hull design (Bustard 1973). A double hull provides a buffer between the cargo and the ice, and additionally provides space for clean ballast (German et al. 1971). During her second voyage to the Arctic, the Manhattan suffered hull damage, but due to the fact that she was being operated in a manner similar to a double-hull ship, no oil was spilled and no damage done to the environment.

Designers of ships intended to be used for one half or more of their working life in ice should give careful consideration to the physical and psychological problems their crews will have to face. For persons aboard ships in the open ocean there is a certain exhilaration in standing on the deck in the salt air watching the ever-changing surface of the sea. The darkness of the winter months and the cold of the Arctic will, however, remove from them the diversion provided by their surroundings. Quarters on commercial ice-transitting ships may, therefore, have to resemble those provided for the oil-drilling crews operating on the North Slope of Alaska.

Vibration reduces the habitability of many ships operating in the open ocean. 
It is not difficult to imagine the more severe problems existing on an icebreaker working its way through varying thicknesses, and sometimes ridges, of ice while the propeller blades remorselessly pound it. If ships are to make their way through ice commercially, methods must be found for minimizing the transmission of vibration into the crew's living areas.

\section{VESSEL OPERATIONS}

The design of a ship for icebreaking service defines to a large extent the capability of the ship of being navigated in ice. Experience in the Arctic has shown, however, that a properly trained and experienced crew can add substantially to the icebreaking capability of a ship. While the Carino was on icebreaking operations in $M^{\prime}$ Clure Strait in the summer of 1974, the presence on board of a captain whose "sense" of the ice enabled him to identify the existence of a lead twenty miles away permitted the ship and its companion vessel, the Arctic Explorer, to proceed west into the strait.

The regulations for crew members set forth in the Canadian Arctic Waters Pollution Prevention Act (S.C. 1970) are not particularly restrictive, requiring only that an ice navigator be aboard each tanker navigating in the Arctic and any other ship operating in a zone beyond its design capability. To qualify as an ice navigator a master need have only five days of experience on a ship operating in ice which is beyond the capability of the ship, and ordinary members of crew are not required to have any special training.

The commercial icebreaking ship will have to operate unaided; that is, its machinery, hull and navigational systems will need to be designed to prevent a complete breakdown in ice. The fallibility of mechanical systems is such, however, that outside icebreaker assistance may be required. In the past, the volume of traffic moving in Arctic waters has been sufficiently small for governments to be able to provide any necessary icebreaker assistance. Ice-transitting transportation systems having a significant number of ships, however, require icebreakers to be on call at critical points of their routes. The economic burden of such a support service would probably then have to be carried by the system itself. As multiple transportation systems using the same routes develop, however, the ability of the commercial vessels to assist each other may reduce the need for outside icebreaker support to a level which can again be financed by governments.

To reach his destination as rapidly as possible and with minimum expenditure of fuel, the master of the commercial icebreaking ship will need information on the ice conditions ahead of him. Although great advances have been made in the determination of ice coverage of navigable waters, means of obtaining full information concerning thickness, strength, snow cover, concentration, flow size and pressure must be devised. The ship-based helicopter has provided a means for the master to survey ice conditions and weigh alternatives. The employment of helicopters on commercial icebreaking ships would, however, constitute a heavy financial burden. Their value in saving time and fuel for the ship would have to be weighed against the effectiveness of other ship-routing techniques. Photographs and other forms of imagery from satellites are now 
available and may be correlated with known information concerning ice conditions on the seas to provide means of guiding icebreaking ships. Information obtained with the aid of satellites may also be combined with the results of sealevel observations to form the basis of a reliable system of ice forecasting, aided perhaps by computer-based simulations.

In Fig. 1 are presented data, obtained from past records, of ice conditions on one Arctic route.

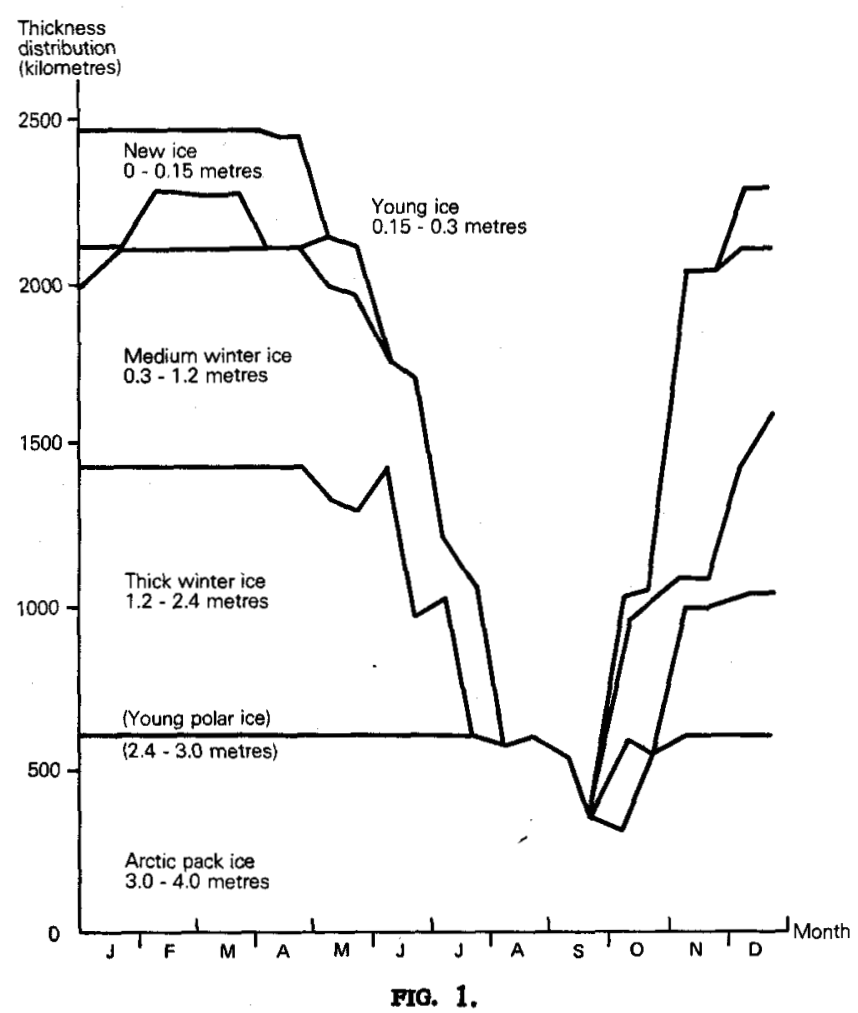

Difficulties in navigation will be caused to icebreaking ships not only by surface ice itself but also by the difficulty it causes in locating navigational aids such as buoys on the surface. Hydrographic information on Arctic waters is sparse and not altogether accurate. During its 1973 seismic shoot, the Carino encountered many shallow waters which were not indicated on charts. In areas such as the Bering Sea, there are many sea-bottom anomalies which pose a significant danger to a ship with a sixty-foot draught. Some method of avoiding or identifying the anomalies must be found if icebreaking ships are to move with safety.

The topography of the ocean bottom and the narrowness of some passages in the Arctic make accurate and reliable navigation systems a necessity for commercial icebreaking ships; and the need for continuous, accurate positioning is best served by installation on the ships of satellite navigation systems and/or 
dead-reckoning computers to supplement navigation systems such as loran, which are based on shore facilities.

\section{THE DESIGN OF TERMINALS}

Terminals for commercial icebreakers are almost as troublesome to design as the ships themselves. Finding a suitable location for a terminal is difficult, particularly on the parts of the Alaskan coast where shallow water extends some distance from the coastline. Dredging may be a possible solution where the water is shallow, though the presence of ice may interfere with it.

Terminals must remain relatively clear of large floe ice at all times so that ships can manoeuvre to the berth. Bottom-anchored single point moorings with a conical shape at the water-line have been suggested as a means of breaking ice in the vicinity of a berthing area, while jetties may be used to form a type of harbour around one, and so keep ice away from it. It is encouraging to note that the causeway at Prudhoe Bay has withstood several winters of attack by ice.

Other proposals for the design of terminals for icebreaking ships involve the use of artificial or mechanical means to keep clear paths to the berths. Bubbler (i.e. air-circulation) systems have been used in temperate climates to keep boat moorings free of ice, and mechanical circulators accomplish the same purpose. However, neither system can be effective when a terminal is located in an area subject to ice drift. There a mechanical system appropriate to local conditions must physically break the ice into pieces sufficiently small for the ships not to need to break the ice as they move at slow speed towards their berths. If more complex systems prove impractical, an icebreaker located at the terminal may prove to be very suitable for keeping it clear.

Since oil is one of the prime cargoes expected to be moved from the Arctic, the problem of possible oil spills at terminals must be considered early in their designing. At well-operated terminals for oil tankers, excellent records of avoiding oil spills have been maintained. At mono-mooring terminals special precautions have to be taken, since any spill will occur in the midst of broken ice, and so present a most difficult clean-up task. As always, however, the key to avoiding ecological damage in the Arctic is prevention, not cure.

The pipelines which feed oil to the terminals will have their own special problems. Perhaps the worst is that of scour in the vicinity of the shoreline. Pipelines will have to be buried as they enter the water and, in permafrost areas, insulated or traced with refrigerant lines to maintain the permafrost.

\section{COMMERCIAL SYSTEMS ANALYSIS}

The foregoing analysis has concerned the marine elements of an Arctic transportation system. Shipbuilders, however, realize that those elements must be seen in relation to the entire system if the resources of the Arctic are to be transported to market. In this section, therefore, consideration is given to elements which are not directly related to vessels and their operations, but which nevertheless are very important in any economic analysis of the system. 
An Arctic transportation system does not solely involve ice operations. For part of any voyage or part of any year, open water will be available. It was noted earlier in this paper that the use of vessels with high length-to-beam ratios was advantageous in ice operations. In temperate waters, however, tankers and bulk carriers are characterized by relatively low length-to-beam ratios.

It has been indicated through the employment of new techniques in economic analysis that ratios will be even lower in the future. A design anomaly is therefore introduced into the system of transportation: is it better to have a broad vessel that can haul cheaply in open water and expensively in ice, or the reverse?

A perfect example of the use of open water is provided by the annual movement of barges to Prudhoe Bay with supplies. Similar situations occur in the Canadian Arctic with the delivery of equipment and supplies during the summer in non-icebreaking equipment. In order to render these operations more econornic, or to make for a smoother supply pattern, it would be necessary to provide some degree of icebreaking ability. The extension of the navigation season in the Great Lakes is an outstanding case in point.

The seasonal variation in the amount of ice produces corresponding variation in the throughput of a system of transportation. For most cargoes which are to be carried from the Arctic there is a desire on the part of the producer of the cargo to maintain production at a nearly constant level throughout the year. In the case of oil, the output of a field can be varied, but the best practice is to maintain wells at a constant rate of production.

Speed of consumption of cargo varies seasonally. In the case of oil, demand at the refinery fence reaches a peak in the spring and the fall, as the refiners produce gasoline for the summer and fuel oil for the winter. The fall peak coincides with the best ice conditions of the year; the spring peak coincides with the worst.

A properly designed system of transportation will include methods for dealing with the seasonal variability of throughput and demand. One technique which can be used is to construct storage facilities at the producing and consuming ends. Facilities at the producing end must be large enough to store the constantly produced cargo while ships are working against the ice. When the ice breaks up in the summer, and the ships can move productively, the storage is emptied. From variability in throughput shown in Fig. 2, it may be seen that seven days of storage would be required at the producing end to maintain the production rate, and seven days at the consuming end, to even out deliveries.

A second technique for dealing with the problem of seasonal variability is to reduce the speed of the ships as the ice conditions improve. This technique is being used today by some tanker operators who have capacity surplus to their needs. Instead of running their ships at design speed and having them wait for cargoes, they are slowing the ships to reduce their throughput capability.

A third technique is possible with a fleet consisting of six or more ships: by the proper scheduling of annual maintenance periods, the throughput of the system can be maintained nearly constant. The use of this technique with the throughput variability of Fig. 2 is demonstrated in Fig. 3. If maintenance is carried out during the summer, the variation in throughput is nearly eliminated. 


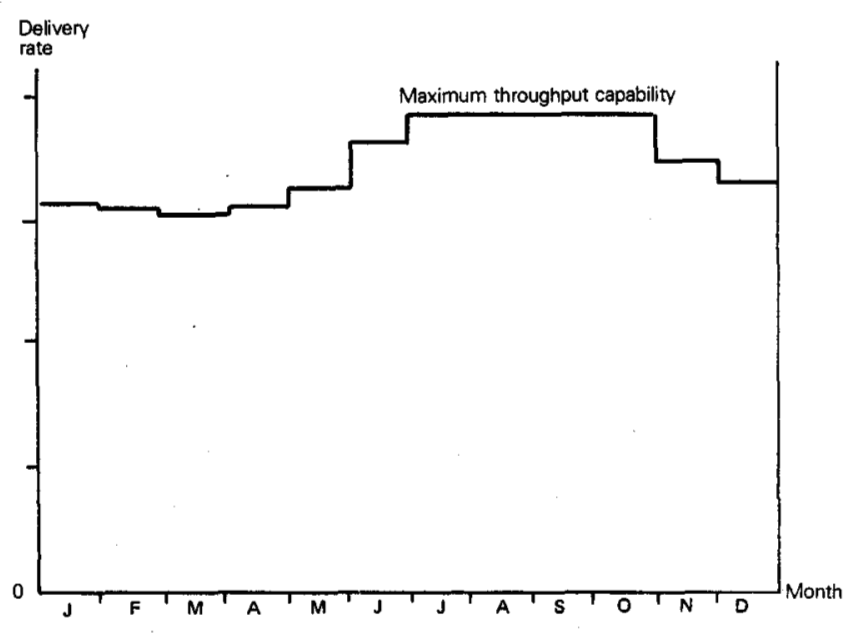

FIG. 2.

Ideally, the system should have sufficient slack to permit one vessel to be out of service at any time during the year. This is possible with systems having a large throughput relative to the size of the ships.

The very existence of the ice and the changes which the presence of this one element makes necessary in the design of a ship introduce to the mind of the designer of a system of transportation the idea of using the icebreaker ship solely in its special element and using standard ships in ice-free areas, with some sort of transhipment terminal in the border area as a necessary consequence.

In the case of oil cargoes, however, the presence of a transhipment terminal introduces two additional transfers of oil. Since the basic system provides for only two transfers, the addition of the transhipment terminal doubles the risk of oil spillage, even though it can be minimal if the terminal is well designed and operating procedures are well planned.

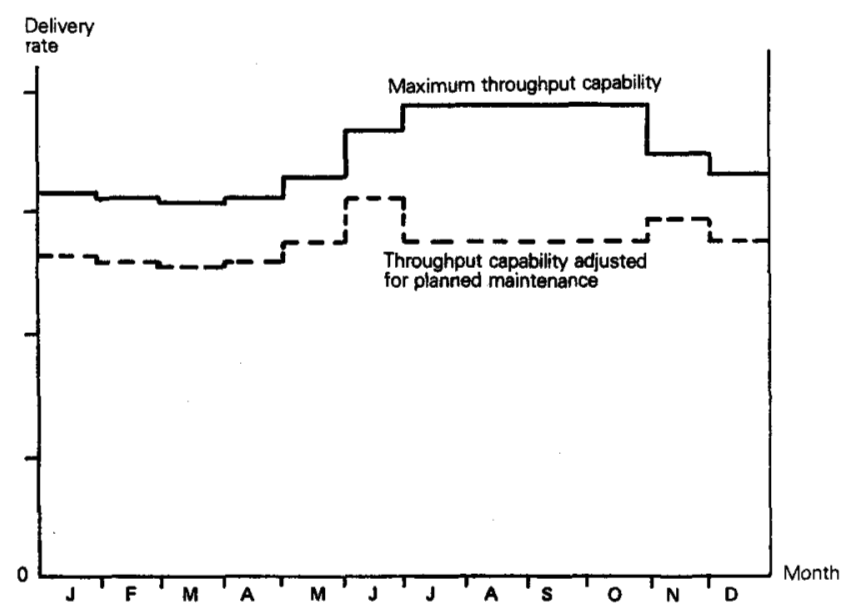

FIG. 3. 
From the standpoint of ship utilization, the transhipment terminal should be located as close to the winter limit of the ice as is prudent. The proximity of the terminal to the edge of the ice means, however, that the terminal is subject to the weather problems which characterize the presence of cold air over warmer water: fog and rough conditions give rise to ship handling and docking problems which would not be present if the transhipment terminal were not included in the system, and great care and dexterity will be required on the part of the crew manning it. They will be living and working under conditions not very dissimilar from those of the crews on the icebreaking ships, and their working conditions must be good.

Another disadvantage of using a transhipment terminal in an icebreaking transportation system is that the problem of variation in throughput becomes much more acute. With the transhipment terminal, the percentage of the route length which is covered by ice is very large, as is also the variation of the percentage of ice-covered route length. Indeed, the reason for using the transhipment terminal is to bring the percentage of the route length which is ice-covered as close to $100 \%$ as possible. During the summer, however, the breakup of the ice reduces substantially the amount of ice encountered by the icebreaker which in many cases therefore can achieve speeds and capacity for throughput nearly equal to that of the open-water ship.

The effect of this problem is shown in Fig. 4 for the same route shown in Fig. 2. In addition to aggravating the throughput variation, the use of the transhipment terminal reduces the number of icebreaking ships and the potential for using planned maintenance outages as a means of smoothing the throughput curve. For the case shown in Fig. 4, careful scheduling does permit a nearly level throughput curve, but any unanticipated ship failure, particularly in the winter season, would have a severe impact on the throughput capability.

An exercise in optimization involving speed, capacity and storage is always necessary to achieve the most economic system of transportation.

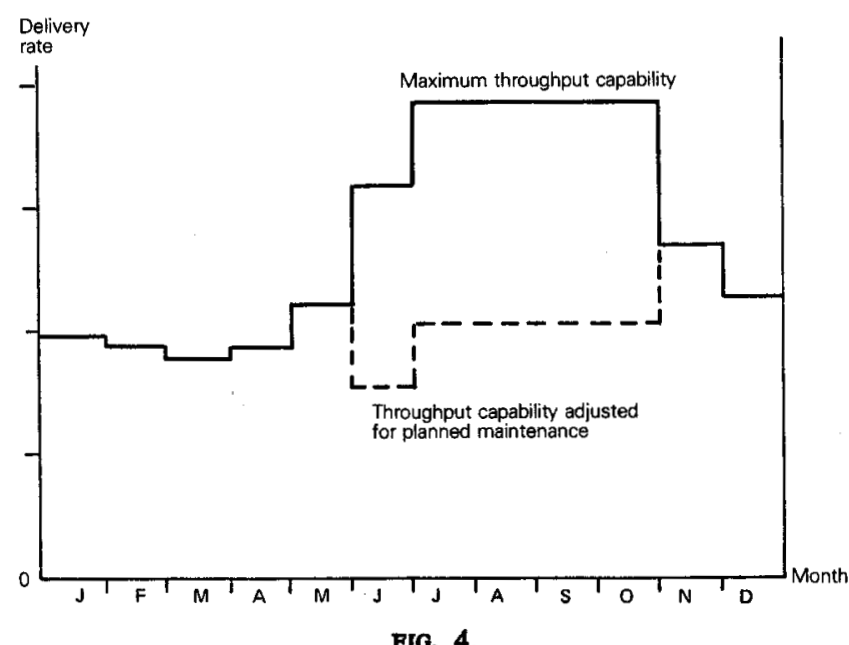

FIG. 4. 
In the last several years, optimization techniques involving the use of computers have been developed which can help solve the problem of what is the best ship or transportation system; however, for these techniques to work it is necessary for much data to be supplied.

Some writers (e.g., German 1970) have observed that, in comparing several alternative transportation systems, it is almost useless to make generalized comparisons of alternatives. Each proposed route with its associated terminals and commodity make up a unique set of conditions. It is therefore very dangerous to establish a vessel system or vessel size prior to making a detailed analysis of the physical and economic parameters of the project.

From the above premise one might assume that all projects must be commenced as fresh exercises. This is not true. Just as the design of any new vessel or transportation system relies on the experience and knowledge gained in previous work, so does the analysis of an Arctic system. The problem is that the increase in knowledge of each new project must be catalogued systematically in order that subsequent systems may benefit from the previous analysis.

Today maritime transportation systems for the Arctic are at a pivotal point. Past systems have not been considered viable. However, knowledge of the Arctic environment has increased greatly, and by using it with the aid of modern analytical techniques it may soon be possible to show that Arctic transportation systems are both technically and economically viable.

\section{REFERENCES}

BUSTARD, E. E. 1973. Merchant ships for the Canadian Arctic, Parts 1, 2. Marine Engineers Review: November 1973, pp. 23-28; December 1973, pp. 15-19.

GERMAN, G. J. 1970. Bulk shipping and icebreaker support in the Arctic. Proceedings of the Arctic Transportation Conference, 1970. Ottawa: Information Canada.

, COLLINS, C. F. and WEBSTER, A. R. 1971. Some considerations in the design of polar icebreakers. Marine Technology, 9 (1): $42-58$.

LEVINE, G. H., VOELKER, R. R. and MENTZ, P. B. 1974. Advances in the Development of Commercial Ice-Transiting Ships. New York: Society of Naval Architects and Marine Engineers (Transactions, vol. 82.)

MILANo, v. R. 1973. Ship Resistance to Continuous Motion in Ice. New York: Society of Naval Architects and Marine Engineers (Transactions, vol. 81).

S. C. (Statutes of Canada). 1970. Canadian Arctic Waters Pollution Prevention Act. 